\title{
Studies of the rate of passage and disappearance in the intestine of the goat of carotene dissolved in fat and mixed with chromium sesquioxide
}

\author{
By E. C. OWEN, R. A. DARROCH AND R. PROUDFOOT \\ Hannah Dairy Research Institute, Kirkhill, Ayr \\ (Received 3 I March 1958-Revised I4 August 1958)
}

Carotene is usually eaten by animals as a natural constituent of some portion of their food, and in previous experiments Chanda, Clapham, McNaught \& Owen ( 195 I $a, b$ ) and Chanda \& Owen (1952) provided either grass meal or lucerne leaf meal as a source of carotene. In those experiments chromium sesquioxide, $\mathrm{Cr}_{2} \mathrm{O}_{3}$, intimately mixed with the food was used as a marker. In the following experiments the loss of carotene dissolved in fat was studied by giving to goats gelatin capsules containing both carotene and $\mathrm{Cr}_{2} \mathrm{O}_{3}$ at the rate of one capsule daily. The aim of the experiments was (a) to show that carotene and $\mathrm{Cr}_{2} \mathrm{O}_{3}$ which enter the gut together pass through it together, $(b)$ that therefore the ratio of carotene to $\mathrm{Cr}_{2} \mathrm{O}_{3}$ in the faeces may be used as an index of the digestion of carotene, and $(c)$ to compare the disappearance of carotene dissolved in fat with that of carotene naturally occurring in greenstuff.

\section{EXPERIMENTAL}

Animals and their feeding. There were four experiments. In each of the first three, the same goat, a non-lactating British Saanen female, was used to investigate the rate of appearance in the faeces of residual carotene from a single dose of $\mathrm{Cr}_{2} \mathrm{O}_{3}$-carotene mixture given in a single capsule. In the fourth experiment such capsules were administered at the rate of one daily for several days to each of five lactating British Saanen female goats. The animals were confined in crates (Crossland, Owen \& Proudfoot, $195^{8}$ ) which enabled faeces to be gathered every time the animals defaecated. Throughout the experiment the goats were given a diet free from carotene or any other known precursor of vitamin A. In Exps. I-3, the diet contained bruised oats, bean meal (Vicia faba), beet pulp and oat straw. The goat received at 7 a.m. and 4 p.m. I lb. of a mixture of three parts by weight of oats to two of bean meal, together with $\mathrm{I} l \mathrm{lb}$. of beet pulp. At noon it was given $\frac{1}{2} \mathrm{lb}$. of oat straw. The goat ate this food completely every day. Drinking water was always available.

The five goats in Exp. 4 received throughout the whole experiment a mixture containing three parts by weight of crushed oats and two of bean meal. Each goat was given $\mathrm{I}_{2} \mathrm{lb}$. at the morning milking and another $\mathrm{I} \frac{1}{2} \mathrm{lb}$. at the afternoon milking, together with oat straw to appetite. Before the beginning of each experiment these diets were given until the faeces were found by analysis to contain xanthophyll but no carotene. One capsule was then administered by dosing gun in each of Exps. I-3. 
In Exp. 4 one capsule daily was given to each of the five goats for the 7 consecutive days of period 1 , after which I I days elapsed before capsules were again given in periods 2 and 3 , each 9 days long. Period 3 followed period 2 without a break. In Exps. I-3 every sample of faeces was collected and bottled for analysis immediately after defaecation, but in Exp. 4 the whole day's output of faeces was mixed with a spade and a I lb. kilner jar was filled to provide a sample for analysis. Before analysis samples were stored in refrigerators at $4^{\circ}$ in Exp. 4 and at $-18^{\circ}$ in Exps. $1-3$.

Chemical methods. For analysis the $\mathrm{I} \mathrm{lb}$. samples were passed through a domestic mincer to ensure thorough mixing and were immediately analysed for carotene. Samples from the same minced faeces were later analysed for $\mathrm{Cr}_{2} \mathrm{O}_{3}$. All analyses were done in duplicate. The chemical methods for carotene and chromium were as described by Chanda et al. (195 I $a$ ) except that, in Exps. I-3 where, owing to the frequency of collection, the samples were necessarily smaller, $2 \mathrm{~g}$ samples of faeces were ashed directly in nickel crucibles before addition of the sodium carbonate. Dry matter in faeces was determined by heating to a constant weight in an oven at $100^{\circ}$.

Preparation of carotene and $\mathrm{Cr}_{2} \mathrm{O}_{3}$ mixture. The mixture was prepared from vitaminfree margarine 9o, olive oil 27 and $\alpha$-tocopheryl acetate (Roche Products Ltd) 5 parts by weight. Into this mixture the $\mathrm{Cr}_{2} \mathrm{O}_{3}$ and $\beta$-carotene (British Drug Houses Ltd) were incorporated so that half the weight of the resulting mixture was due to $\mathrm{Cr}_{2} \mathrm{O}_{3}$. Mixing was done on a sheet of glass with a stainless steel knife. Efficiency of mixing was considered essential to ensure that in Exps. I- 3 the portion of the sample analysed had the same composition as the portion eaten, and to ensure in addition that in Exp. 4 the intakes of carotene and $\mathrm{Cr}_{2} \mathrm{O}_{3}$ did not vary from one day to the next. Tests showed that such mixtures were stable over the period of the experiment when stored in a dark bottle in a refrigerator. Uniformity of mixing was tested by dissolving samples of the mixture in light petroleum (b.p. $60-80^{\circ}$ ), spinning down the $\mathrm{Cr}_{2} \mathrm{O}_{3}$ in weighed centrifuge tubes and measuring, after appropriate dilution, the absorption of the resulting solution at $45 \mathrm{I} \mathrm{m} \mu$. The sediment of $\mathrm{Cr}_{2} \mathrm{O}_{3}$ was washed with petroleum and centrifuged again, the washing being done three times in all. The tubes were dried in an oven at $100^{\circ}$, cooled in a desiccator and re-weighed. Results for both $\mathrm{Cr}_{2} \mathrm{O}_{3}$ and carotene in duplicate parts of a mixture taken from different parts of the mass agreed to within less than $I \%$, irrespective of whether the samples analysed weighed 500 , 100 or $20 \mathrm{mg}$. On samples of 4 or $5 \mathrm{mg}$, discrepancies were $20 \%$ for $\mathrm{Cr}_{2} \mathrm{O}_{3}$ and $25 \%$ for carotene. In Exp. 4 a ro $\mathrm{g}$ sample of faeces taken for analysis contained about $20 \mathrm{mg}$ of the mixture of carotene and $\mathrm{Cr}_{2} \mathrm{O}_{3}$. Amounts weighing 2.0000 \pm $0.0004 \mathrm{~g}$ were placed in gelatin capsules of size no. 000 (Parke, Davis \& Co. Ltd, Hounslow). The amount of $\mathrm{Cr}_{2} \mathrm{O}_{3}$ in each capsule in Exps. I-3 is shown in Table $\mathrm{I}$. In period I of Exp. 4, 34.00 $\mathrm{mg} \beta$-carotene and $\mathrm{I} \cdot \mathrm{II} 2 \mathrm{~g} \mathrm{Cr}_{2} \mathrm{O}_{3}$ were present in each capsule, and in periods 2 and $3,26.77 \mathrm{mg} \beta$-carotene and $\mathrm{I} \cdot 093 \mathrm{~g} \mathrm{Cr}_{2} \mathrm{O}_{3}$.

The ready solubility of the gelatin of the capsules was confirmed by suspending empty ones in a nylon tricot bag by nylon thread in the rumen of a fistulated steer. Rapid solution of the capsules resulted. 
RESULTS

\section{Experiments I-3}

The time elapsing between the administration of the capsule and the first sample of faeces to contain carotene and $\mathrm{Cr}_{2} \mathrm{O}_{3}$ varied from 9 to $\mathrm{I}_{4} \mathrm{~h}$ (Table $\mathrm{I}$ ). In Fig. I the patterns of excretion in the faeces of dry matter, carotene and $\mathrm{Cr}_{2} \mathrm{O}_{3}$ in Exp. $\mathrm{I}$ are

Table I. Correlation between the percentages of $\beta$-carotene and $\mathrm{Cr}_{2} \mathrm{O}_{3}$ in faecal dry matter from a British Saanen goat dosed on three different occasions with a single capsule containing $2.0000 \mathrm{~g}$ of a mixture of $\mathrm{Cr}_{2} \mathrm{O}_{3}$ and $\beta$-carotene dissolved in fat

Weight of carotene in capsule $(\mathrm{mg})$

Weight of $\mathrm{Cr}_{2} \mathrm{O}_{3}$ in capsule (mg)

Time lapse from feeding to first faecal sample to

Exp. I

Exp. 2.

Exp. 3

contain carotene $(\mathrm{h})$

Time lapse to sample richest in carotene (h)

Time lapse to last collection* (h)

Number of faecal samples collected and analysed

Correlation coefficient, carotene $\times \mathrm{Cr}_{2} \mathrm{O}_{3}$

34
I I 2
14

19
35
14
0.8 I

34
I 122

$14 \quad 12$

$53 \cdot 5$
1000

'Tine when collections were arbitraily $\mathrm{Cr}_{2} \mathrm{O}_{3}$ which later disappeared (see Fig. 2).

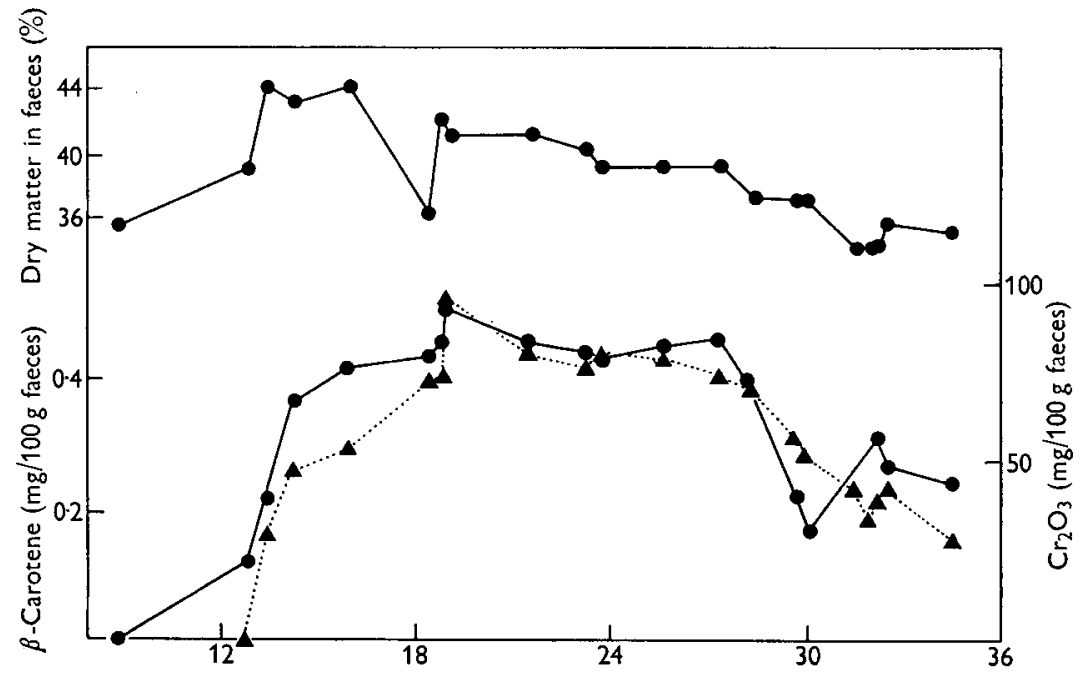

Hours after dosing with a single capsule of $\beta$-carotene- $\mathrm{Cr}_{2} \mathrm{O}_{3}$ mixture

Fig. I. Exp. I. Concentrations of dry matter (upper curve), $\beta$-carotene (ム- - - $\Delta$ ) and $\mathrm{Cr}_{2} \mathrm{O}_{3}(-\bullet)$ in successive faecal samples.

depicted as percentages of each in the faeces samples collected. The faeces sample richest in carotene was also the richest in $\mathrm{Cr}_{2} \mathrm{O}_{3}$ in all three experiments, as can be seen for Exp. $\mathrm{I}$ in Fig. $\mathrm{I}$ in which the maxima of carotene and $\mathrm{Cr}_{2} \mathrm{O}_{3}$ coincide. There was a general parallelism between the percentage of carotene and the percentage of $\mathrm{Cr}_{2} \mathrm{O}_{3}$ in the faeces (Fig. $\mathrm{I}$ ). Because of this parallelism the correlations between the percentages of carotene and $\mathrm{Cr}_{2} \mathrm{O}_{3}$ in the faeces were calculated and gave the coefficients shown in Table $\mathrm{I}$. The nearness of these coefficients to unity supports the 
assumption that undigested carotene and $\mathrm{Cr}_{2} \mathrm{O}_{3}$ remained mixed while passing through the gut.

The percentage of dry matter in the faeces ranged from 34 to 44 in Exp. I (Fig. I), from 22 to 42 in Exp. 2, and from 33 to 47 in Exp. 3. Table 1 shows that in Exp. 2 the animal defaecated far more frequently than in Exps. $\mathrm{I}$ and 3 . This frequency may have been due to the fact that in Exp. 2 the animal came into season shortly after the capsule was given.

If the ratio of carotene to $\mathrm{Cr}_{2} \mathrm{O}_{3}$ in the capsule is $k$ then $k \times \mathrm{Cr}_{2} \mathrm{O}_{3}$ gives the concentration of carotene that would have been present in any given faeces sample if none of the carotene had disappeared. In Fig. 2 each concentration of carotene has been plotted against the concentration of $\mathrm{Cr}_{2} \mathrm{O}_{3}$ in the faeces. The points, each of which represents both the $\mathrm{Cr}_{2} \mathrm{O}_{3}$ and carotene in the same sample, all fall close to the straight line representing the rectilinear regression of carotene on $\mathrm{Cr}_{2} \mathrm{O}_{3}$ with a correlation coefficient of 0.974 (Table 1 ). The regression equation is:

$$
y=\mathrm{I} \cdot 2363-0.03607(x-35 \cdot 4 \mathrm{I}) \text {, }
$$

in which $x$ is the concentration of $\mathrm{Cr}_{2} \mathrm{O}_{3}$ and $y$ the concentration of carotene, both in $\mathrm{mg} / \mathrm{I00} \mathrm{g}$ faeces. The equation shows that when $x=0, y$ is smaller than the smallest faecal concentration of carotene, and that when $y=0, x$ is smaller than the smallest faecal concentration of $\mathrm{Cr}_{2} \mathrm{O}_{3}$, so that only a negligible shifting of the regression line would have resulted if it had been calculated to pass through the origin instead of through the mean of the $\mathrm{Cr}_{2} \mathrm{O}_{3}$ and carotene concentrations. Equation (I) then becomes

$$
y=d x,
$$

where $d=0.035 \mathrm{I} 2 \mathrm{mg}$ carotene $/ \mathrm{mg} \mathrm{Cr}_{2} \mathrm{O}_{3}$. The coefficient, $d$, being an estimate of the ratio of carotene to $\mathrm{Cr}_{2} \mathrm{O}_{3}$ in the faeces, can be used to calculate the digestibility of the carotene in the capsule as follows:

If $F$ represents the fraction of the carotene in the capsule which disappeared, then

$$
F=\mathrm{I}-\frac{y}{k x} .
$$

Combination of equations 2 and 3 gives

Therefore

$$
F=\mathrm{I}-\frac{d x}{k x} .
$$

Therefore $\quad$ 100 $F=100-100 \frac{d}{k}$,

$$
F=\mathrm{I}-\frac{d}{k}
$$

in which $100 F$ represents the percentage of the carotene disappearing.

In Exp. 3, Figs. 2 and 3, this loss was

$$
\begin{aligned}
\mathrm{I} 00 F & =100-\frac{100 \times 0.03512}{0.0535} \\
& =34.4 \% \text { of the carotene administered. }
\end{aligned}
$$


In the foregoing method of calculating the disappearance of carotene only the ratios of carotene to $\mathrm{Cr}_{2} \mathrm{O}_{3}$ in food and faeces have been used, and the intake and output of carotene have been ignored. It is possible, by adding the daily intakes and outputs of carotene, to make an alternative estimate of the loss as follows:

If $a$ represents the weight in $\mathrm{g}$ of any particular faeces sample, if $b$ is $\mathrm{mg}$ carotene/ roo $\mathrm{g}$ of sample, if $c$ represents $\mathrm{mg} \mathrm{Cr}_{2} \mathrm{O}_{3} /$ I00 $\mathrm{g}$ of the sample, and $k$ has the same

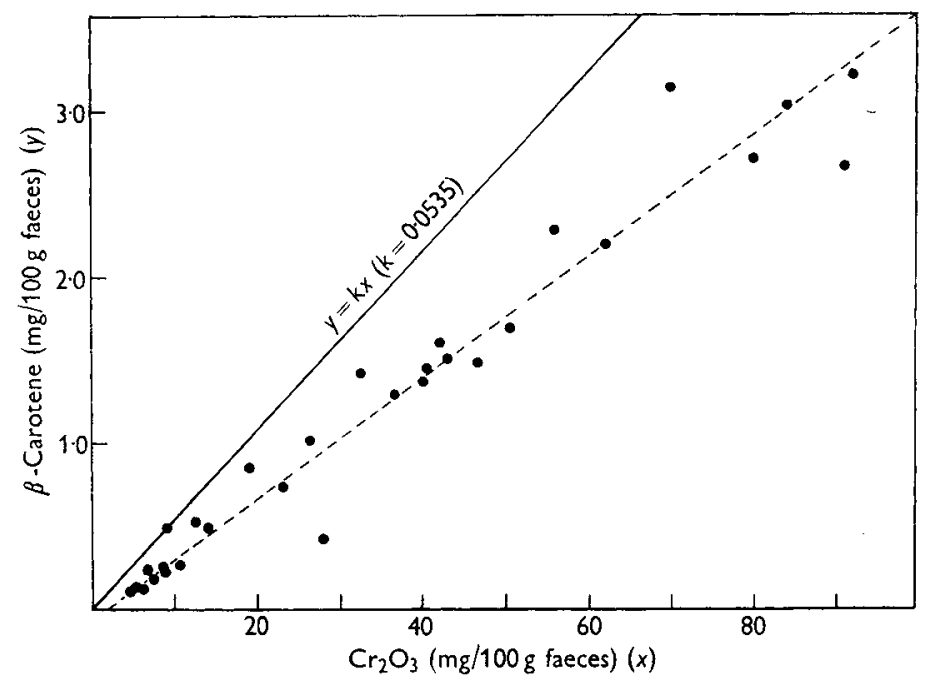

Fig. 2. Exp. 3. Regression of faecal $\beta$-carotene on faecal $\mathrm{Cr}_{2} \mathrm{O}_{3}$. The equation of the regression line is $y=1.2363-0.03607\left(x-35^{\circ} 41\right)$. The full line $y=k x$ is where the regression line would have been expected to lie if all the carotene had reappeared in the faeces.

significance as before, then $\Sigma a b$ will represent the total output of carotene in all the samples considered together, and $\Sigma a c$ will represent the total output of $\mathrm{Cr}_{2} \mathrm{O}_{3}$. The product $k \Sigma a c$ will then represent the total intake of carotene, so that the loss of carotene will be $k \Sigma a c-\Sigma a b$ and the percentage loss of the carotene will be

$$
\mathrm{I} 00 F=\mathrm{IOO}\left(\frac{k \Sigma a c-\Sigma a b}{k \Sigma a c}\right) .
$$

When this formula is applied to the values of Exp. 3 it gives

$$
\begin{aligned}
\text { IOOF } & =\frac{100(0.0535 \times 697.09-24.563)}{0.0535 \times 697.09} \\
& =34 . \mathrm{I} .
\end{aligned}
$$

This percentage loss of carotene agrees very well with the $34.4 \%$ found by the regression method. From the percentage loss calculated by either the regression or the summation method the amount of carotene disappearing after a known intake can be calculated, and the results for Exps. $\mathrm{I}-4$ are given in Table 2, together with some results from one of our earlier experiments (Chanda et al. $195 \mathrm{I} a$ ) in which $\mathrm{Cr}_{2} \mathrm{O}_{3}$ was used to measure the loss of carotene in dried-grass meal supplied to female British Saanen goats which were the progenitors of those used in the present experiments. Table 2 shows that the amounts disappearing agree, whichever of the two methods is 
used for calculation. They also show that the amount of carotene lost from dried-grass meal in the experiments of Chanda et al. ( $195 \mathrm{r} a$ ) was much the same as the amount lost in Exp. 4 when the carotene was dissolved in fat.

The distinct maximum in the concentration of $\mathrm{Cr}_{2} \mathrm{O}_{3}$ in the faeces (Figs. $\mathrm{I}$ and 3 ) indicates the likelihood that if a series of capsules had been given at $24 \mathrm{~h}$ intervals, peaks and troughs of appearance of $\mathrm{Cr}_{2} \mathrm{O}_{3}$ and carotene in the faeces would still have occurred, as indeed the experiments of Raymond \& Minson (I955), who gave $\mathrm{Cr}_{2} \mathrm{O}_{3}$ to sheep, showed.

Table 2. Amount of $\beta$-carotene disappearing from the alimentary tract of British Saanen goats from capsules containing a mixture of $\mathrm{Cr}_{2} \mathrm{O}_{3}$ and $\beta$-carotene dissolved in fat and from dried-grass meal marked with $\mathrm{Cr}_{2} \mathrm{O}_{3}$

\begin{tabular}{|c|c|c|c|c|c|c|}
\hline \multirow[b]{2}{*}{ Experiment } & & \multirow[b]{2}{*}{$\begin{array}{l}\text { Carotene } \\
\text { given as }\end{array}$} & \multirow{2}{*}{$\begin{array}{l}\text { Carotene } \\
\text { intake } \\
(\mathrm{mg} / \text { day })\end{array}$} & \multirow{2}{*}{$\begin{array}{c}\text { No. of } \\
\text { consecutive } \\
\text { days of } \\
\text { administration }\end{array}$} & \multicolumn{2}{|c|}{$\begin{array}{c}\text { Carotene lost* } \\
(\mathrm{mg} / \text { day })\end{array}$} \\
\hline & & & & & (i) & (ii) \\
\hline $\mathbf{I}$ & & Single capsule & $34 \cdot 0$ & I & $28 \cdot 6$ & $28 \cdot 5$ \\
\hline 2 & & & $34^{\circ} \circ$ & I & $29 \cdot 4$ & $27 \cdot 2$ \\
\hline $\begin{array}{l}3 \\
4 t:\end{array}$ & & & $53 \cdot 5$ & I & $18 \cdot 2$ & $18 \cdot 1$ \\
\hline Period & $\begin{array}{l}1 \\
2 \\
3\end{array}$ & One capsule/day & $\begin{array}{l}34 \cdot 0 \\
26 \cdot 8 \\
26 \cdot 8\end{array}$ & $\begin{array}{l}5 \\
8 \\
9\end{array}$ & $\begin{array}{l}\text { I } 9 \cdot 2-22 \cdot 3 \\
\text { I } 2 \cdot 9-2 \text { I } 0 \\
\text { I } 7 \cdot 2-22 \cdot 2\end{array}$ & $\begin{array}{l}21 \cdot 0-24 \cdot 8 \\
\times 3 \cdot 7-21 \cdot 2 \\
16 \cdot 8-22 \cdot 2\end{array}$ \\
\hline Earlier work & & & & & & \\
\hline Goat no: & $\begin{array}{l}\text { I } \\
2 \\
3 \\
4\end{array}$ & Dried-grass meal & $\begin{array}{l}42 \cdot 2 \\
41 \cdot 7 \\
42 \cdot 6 \\
4 x \cdot 4\end{array}$ & $\begin{array}{l}10 \\
10 \\
10 \\
10\end{array}$ & $\begin{array}{l}29 \cdot 5 \\
26 \cdot 3 \\
26 \cdot 5 \\
25 \cdot 3\end{array}$ & - \\
\hline
\end{tabular}

* (i) is calculated from the carotene intake corrected by means of faecal $\mathrm{Cr}_{2} \mathrm{O}_{3}$ and (ii) from the regression of faecal carotene on faecal $\mathrm{Cr}_{2} \mathrm{O}_{3}$.

$\uparrow$ Omitting goat no. 5 in period $I$.

† Calculated from the mean values in Table 3 of Chanda et al. (195 I $a$ ).

The upper curve in Fig. 3 shows the faecal carotene concentrations which.would have been expected if all the carotene had reappeared in the faeces and the lower curve shows the actual carotene concentrations, each abscissa representing the time at which the sample of faeces was collected. Thus the lower curve is the graph of carotene against time and the upper curve is the graph of $k \times \mathrm{Cr}_{2} \mathrm{O}_{3}$ against time, where $k$ is, as before, the ratio of carotene to $\mathrm{Cr}_{2} \mathrm{O}_{3}$ in the capsule. In Fig. 3 the loss of carotene in any sample of faeces is the difference between the two curves at any given time. In Exps. I-3 only $5 \mathrm{~g}$ of the mixed sample of faeces were taken for analysis for carotene as against the $10 \mathrm{~g}$ in Exp. 4. In Exps. $\mathrm{I}-3$ only $2 \mathrm{~g}$ of faeces were taken for $\mathrm{Cr}_{2} \mathrm{O}_{3}$ analysis as against $20 \mathrm{~g}$ in Exp. 4 . The smallness of these samples, together with the fact that it was impracticable to estimate $\mathrm{Cr}_{2} \mathrm{O}_{3}$ in the watery residues from the carotene estimations, must have made the results more variable than they would otherwise have been. In spite of these obvious causes of variability the parallelism of the $\mathrm{Cr}_{2} \mathrm{O}_{3}$ and carotene curves is well demonstrated by Fig. 3 .

Fig. 3 shows measurable carotene and $\mathrm{Cr}_{2} \mathrm{O}_{3}$ in the faeces at the time when collections were discontinued, i.e. over $68 \mathrm{~h}$ after the dose was given. After a lapse of $7^{2} \mathrm{~h}$ 
the amount of $\mathrm{Cr}_{2} \mathrm{O}_{3}$ determined in the faeces, which were free from carotene, was no greater than the analytical blank. In Exps. I-3 there was no residue of carotene in the faeces, such as was observed in cows by Chanda et al. $(195 \mathrm{I} b)$. This difference is attributable to the fact that the Ayrshire cow takes up considerable carotene into its blood along with vitamin A (Chanda, Clapham \& Owen, I954, I955a,b), whereas the British Saanen goat does not absorb carotene in amounts readily detectable in its blood (Chanda \& Owen, unpublished observations).

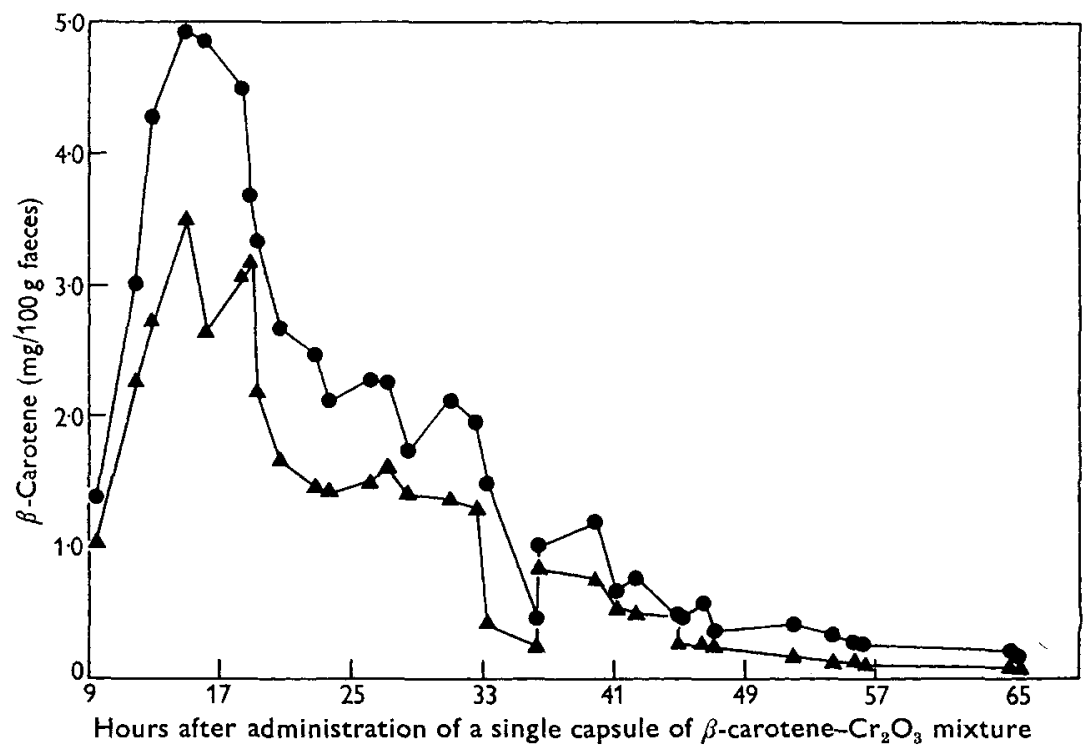

Fig. 3. Exp. 3. Concentration of $\beta$-carotene found in the faeces $(\boldsymbol{\Delta}-\mathbf{\Delta})$ compared with the concentration that would have been expected from their $\mathrm{Cr}_{2} \mathrm{O}_{3}$ content if all of the carotene had reappeared in the faeces $(-\bullet)$.

\section{Experiment 4}

Our earlier experiment (Chanda et al. $195 \mathrm{I} a$ ) having already shown that $\mathrm{Cr}_{2} \mathrm{O}_{3}$ can be completely recovered in the faeces, we assumed that recovery was quantitative in the experiments with capsules in which mixing of the $\mathrm{Cr}_{2} \mathrm{O}_{3}$ and carotene with the ration was necessarily left to the goats themselves. It is known from the experiments of Raymond \& Minson (I955) that $\mathrm{Cr}_{2} \mathrm{O}_{3}$ administered by capsule does not mix uniformly with the faeces. The fact studied by Balch (1950), Balch \& Johnson (I950) and Balch \& Kelly (1950) (see Owen, I954) that roughage passes along the gut at a different rate from other digesta doubtless accentuates this lack of uniformity of mixing in ruminants. It appears to be true also of the pig (Moore, I957, 1958). In the attempt to overcome the lack of uniformity of distribution of the $\mathrm{Cr}_{2} \mathrm{O}_{3}$ and carotene each day's faeces were mixed with a spade before the $\mathrm{I} \mathrm{lb}$. sample was taken for analysis. Tables 3 and 4 show that, in spite of this mixing, the distribution of the $\mathrm{Cr}_{2} \mathrm{O}_{3}$ in the faeces was still uneven. In Table 3 the ratios of the faecal outputs of $\mathrm{Cr}_{2} \mathrm{O}_{3}$ to the daily intakes are given. These values which have a mean of $\mathrm{I} \cdot \mathrm{I} 7$ (range from 0.88 to $\mathrm{I} \cdot 37$ ) show the magnitude of the bias which appears to have been introduced into the 
sampling of the faeces because the $\mathrm{Cr}_{2} \mathrm{O}_{3}$ was in a capsule and was not, as in the experiments of Chanda et al. (195 $\mathrm{I} a, b)$, uniformly mixed with the diet. Table 4 shows the day-to-day variations in the concentrations of $\mathrm{Cr}_{2} \mathrm{O}_{3}$ and carotene in the

Table 3. Exp. 4. Variation of the bias in sampling of the faeces as indicated by the ratio of the faecal output of $\mathrm{Cr}_{2} \mathrm{O}_{3}$ to the intake, each goat being given every day by mouth a $2 \mathrm{~g}$ dose of $\beta$-carotene and $\mathrm{Cr}_{2} \mathrm{O}_{3}$ mixture in a capsule containing I.I I $2 \mathrm{~g} \mathrm{Cr}_{2} \mathrm{O}_{3}$ in period $\mathrm{I}$ and $\mathrm{I} \cdot 093 \mathrm{~g}$ in periods 2 and 3

\begin{tabular}{|c|c|c|c|}
\hline \multirow[b]{2}{*}{ Goat no. } & \multicolumn{3}{|c|}{$\begin{array}{l}\text { Ratio of faecal output of } \mathrm{Cr}_{2} \mathrm{O}_{3} \text { to } \\
\qquad \mathrm{Cr}_{2} \mathrm{O}_{3} \text { in capsule }\end{array}$} \\
\hline & $\begin{array}{l}\text { Period } \mathbf{r} \\
\text { (5 days) }\end{array}$ & $\begin{array}{l}\text { Period } 2 \\
\text { (8 days) }\end{array}$ & $\begin{array}{l}\text { Period } 3 \\
\text { (9 days) }\end{array}$ \\
\hline I & $\begin{array}{r}1 \cdot 32 \\
0.88\end{array}$ & $\begin{array}{l}\text { I } \\
I\end{array}$ & $\begin{array}{l}I \cdot 19 \\
I \cdot 28\end{array}$ \\
\hline 3 & I. I9 & $1 \cdot 28$ & $I \cdot 37$ \\
\hline 4 & $I \cdot I I$ & $\mathbf{I}{ }^{*} \mathbf{I} \mathbf{I}$ & I'I I I \\
\hline 5 & 0.89 & $I \cdot I 6$ & I'I 5 \\
\hline Mean & I.08 & $1 \cdot 20$ & $I \cdot 22$ \\
\hline
\end{tabular}

Table 4. Exp. 4. Output and composition of faeces of goat no. 3 in period 2

\begin{tabular}{|c|c|c|c|}
\hline $\begin{array}{l}\text { Day } \\
\text { no. }\end{array}$ & $\begin{array}{c}\text { Output of } \\
\text { faeces } \\
(\mathrm{kg} / \text { day }) \\
(a)^{*}\end{array}$ & $\begin{array}{c}\beta \text {-Carotene } \\
\text { in faeces } \\
(\mathrm{mg} / 100 \mathrm{~g}) \\
(b)^{*}\end{array}$ & $\begin{array}{c}\mathrm{Cr}_{2} \mathrm{O}_{3} \text { in } \\
\text { faeces } \\
(\mathrm{mg} / \mathrm{I} 00 \mathrm{~g}) \\
(c)^{*}\end{array}$ \\
\hline $\begin{array}{l}1 \\
2\end{array}$ & $\begin{array}{l}I \cdot 647 \\
2 \cdot 620\end{array}$ & $\begin{array}{l}0.210 \\
0.670\end{array}$ & $\begin{array}{l}12 \cdot 49 \\
76 \cdot 13\end{array}$ \\
\hline 3 & $2 \cdot 197$ & 0.957 & 65.40 \\
\hline 4 & $2 \cdot 133$ & $0.45^{6}$ & $67 \cdot 63$ \\
\hline 5 & $2 \cdot 033$ & 0.543 & $74 \cdot 87$ \\
\hline 6 & $2 \cdot 120$ & $0 \cdot 369$ & $59 \cdot 3 \circ$ \\
\hline 7 & $2 \cdot 407$ & 0.562 & $48 \cdot 30$ \\
\hline 8 & $2 \cdot 129$ & 0.582 & $59^{\circ} \mathrm{I} 4$ \\
\hline 9 & I.9O2 & 0.697 & $5^{8 \cdot 59}$ \\
\hline
\end{tabular}

faeces during a typical period for one of the goats in Exp. 4. In calculating the percentage loss of carotene, formula (5) enables allowance to be made for this bias in sampling. The loss of carotene (omitting day no. I) is

$$
\begin{aligned}
I 00 F & =\frac{100\left(k \sum a c-\Sigma a b\right)}{k \Sigma a c} \\
& =\frac{100(k \times \operatorname{III} 89-106 \cdot 3)}{k \times \operatorname{III} 89} .
\end{aligned}
$$

In this period

$$
\begin{aligned}
k & =\frac{26.77 \mathrm{mg} \text { carotene in capsule }}{1093 \mathrm{mg} \mathrm{Cr} \mathrm{Cr}_{2} \mathrm{O}_{3} \text { in the capsule }} \\
& =0.02449,
\end{aligned}
$$

which when substituted in equation (6) gives a loss of $61 \cdot 2 \%$.

It was found that on the ist day of periods I and 2 each of the five goats gave, as was 
expected, low outputs of both carotene and $\mathrm{Cr}_{2} \mathrm{O}_{3}$. For this reason these days were omitted from all calculations, though their omission made little difference to the calculation. It is clear that the result is not altered by considering the mean daily output of carotene and $\mathrm{Cr}_{2} \mathrm{O}_{3}$ rather than the sum over the whole period, and in Table 5 the percentage loss for all the goats for each period has been worked out by this ratio method from the mean daily figures shown in the table. As in Exps. I-3 an independent estimate of the loss of carotene may be calculated by the ratio method, the slope of the regression line of carotene on $\mathrm{Cr}_{2} \mathrm{O}_{3}$ in the faeces being used as an estimate of the ratio of carotene to $\mathrm{Cr}_{2} \mathrm{O}_{3}$ in the faeces of a particular goat in a particular period, by means of equation (2) which ignores outputs of faeces. In Fig. 4 the regression line $(y=d x)$ for periods 2 and 3 of goat no. 3 is shown, as also is the line $(y=k x)$ which would have been expected if all of the carotene had reappeared in the faeces. The percentage loss calculated by regression is compared with that calculated by summation in Table 5 . Table 5 shows a reasonable concordance between the results obtained by these two different methods.

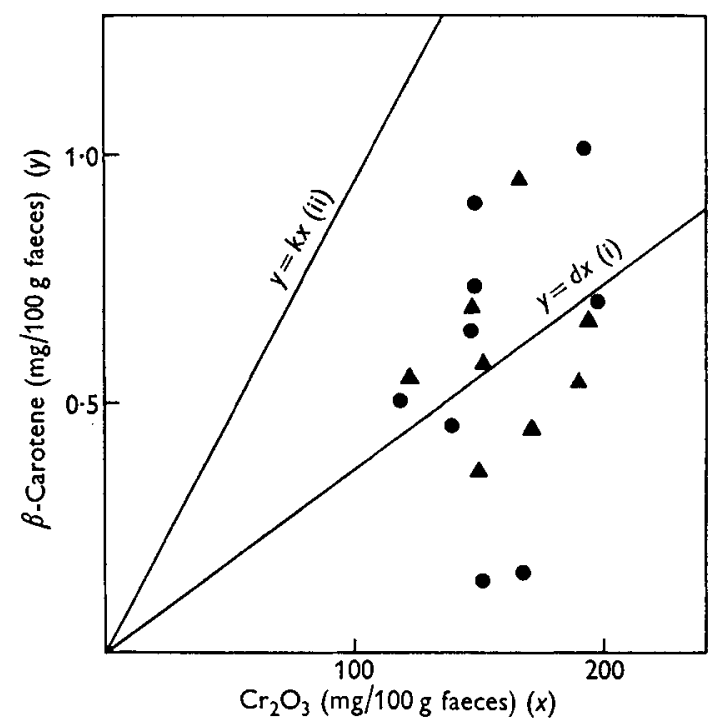

Fig. 4. Exp. 4. Regression of faecal $\beta$-carotene on faecal $\mathrm{Cr}_{2} \mathrm{O}_{3}$ for goat no. 3 in period 2 ( 4 ) and period $3(\bullet)$. (i) is the regression line with slope $=d$ (see p. 29); (ii) would have been the regression line if all the carotene had been excreted in the faeces, i.e. $k=$ ratio of carotene to $\mathrm{Cr}_{2} \mathrm{O}_{3}$ in the capsules.

From Table 5 it is obvious that goat no. 5 behaved differently from the others in period I, and by both methods of calculation the loss of carotene was small for this period. Apart from this one exception, a feature of Exp. 4 was the constancy of the amount of carotene disappearing in all the goats in each period; a mean of $18.4 \mathrm{mg}$ carotene/day was lost, which is $54 \%$ of the quantity administered (Tables 2 and 5 ). The intakes of carotene and the amount of carotene disappearing in Exps. I-4 are shown together in Table 2. In the number of days shown in each period of Exp. 4 in Table 2, the initial days of periods $\mathrm{I}$ and 2 have been omitted for the reason already 
given. The results in Table 2 are too few to permit of generalization, but they do show that the availability of carotene from grass is of the same order as its availability from solution in fat. It is perhaps also noteworthy that in Exps. $1-3$, all of which were done on the same animal, the amount of carotene lost was smaller in Exp. 3 than in Exps. I and 2. Since Exp. I was done in January, Exp. 2 in March and Exp. 3 in May, the supposition that there is a seasonal effect on the assimilation of carotene deserves attention. There is other evidence in favour of such a belief in the experiments of Stewart, McCallum \& Watts (1952) who showed that liver reserves of vitamin A in cattle are lowest in summer, and in the experiments of Keener, Bechdel, Guerrant \& Thorp (1942) who found that the calf's requirement for carotene was larger when the weather was colder. Experiments to test this hypothesis are now being planned.

Table 5. Exp. 4. Losses of $\beta$-carotene dissolved in fat and mixed with $\mathrm{Cr}_{2} \mathrm{O}_{3}$ from the alimentary tract of goats. The losses were calculated by two methods using (i) the weight of faeces produced per day (see Table 4) and (ii) only the regression of carotene concentration on $\mathrm{Cr}_{2} \mathrm{O}_{3}$ concentration in the faeces (see p. 29)

\begin{tabular}{|c|c|c|c|c|c|c|}
\hline \multirow[b]{2}{*}{$\begin{array}{c}\text { Goat } \\
\text { no. }\end{array}$} & \multirow[b]{2}{*}{$\begin{array}{c}\text { Period } \\
\text { no. }\end{array}$} & \multirow[b]{2}{*}{$\begin{array}{c}\text { Carotene } \\
\text { output } \\
\text { (mg/day) } \\
(e)\end{array}$} & \multirow[b]{2}{*}{$\begin{array}{c}\text { True carotene } \\
\text { intake* } \\
\text { (mg/day) } \\
(f)\end{array}$} & \multirow[b]{2}{*}{$\begin{array}{c}\text { Carotene } \\
\text { lost } \\
\text { (mg/day) } \\
(f-e)\end{array}$} & \multicolumn{2}{|c|}{ Loss $(\%)$} \\
\hline & & & & & $\frac{100(f-e)}{f}$ & $100\left(\mathrm{I}-\frac{d}{k}\right)$ \\
\hline I & $\begin{array}{l}1 \\
2 \\
3\end{array}$ & $\begin{array}{l}20 \cdot 22 \\
I 4 \cdot 82 \\
I I \cdot I I\end{array}$ & $\begin{array}{l}39 \cdot 61 \\
27 \cdot 68 \\
31 \cdot 77\end{array}$ & $\begin{array}{l}\text { I } 9.39 \\
\text { I } 2.86 \\
20.66\end{array}$ & $\begin{array}{l}49 \cdot 0 \\
46 \cdot 5 \\
65 \cdot 0\end{array}$ & $\begin{array}{l}54 \cdot 3 \\
49 \cdot 3 \\
66 \cdot 9\end{array}$ \\
\hline 2 & $\begin{array}{l}\mathbf{x} \\
2 \\
3\end{array}$ & $\begin{array}{l}16.77 \\
16.00 \\
13.96\end{array}$ & $\begin{array}{l}39 \cdot 08 \\
36 \cdot 27 \\
34 \cdot 36\end{array}$ & $\begin{array}{l}22 \cdot 31 \\
20 \cdot 27 \\
20 \cdot 40\end{array}$ & $\begin{array}{l}57^{\cdot 1} \\
55^{\cdot} \cdot 9 \\
59^{*} 4\end{array}$ & $\begin{array}{l}56 \cdot 8 \\
57 \cdot 8 \\
59 \cdot 4\end{array}$ \\
\hline 3 & $\begin{array}{l}\text { I } \\
2 \\
3\end{array}$ & $\begin{array}{l}\text { I } 8 \cdot 74 \\
\text { I } 3 \cdot 29 \\
\text { I } 4 \cdot 44\end{array}$ & $\begin{array}{l}40 \cdot 33 \\
34 \cdot 26 \\
36 \cdot 63\end{array}$ & $\begin{array}{l}21 \cdot 59 \\
20 \cdot 97 \\
22 \cdot 19\end{array}$ & $\begin{array}{l}53 \cdot 5 \\
61 \cdot 2 \\
60 \cdot 6\end{array}$ & $\begin{array}{l}6 r \cdot 6 \\
6 I \cdot 8 \\
60 \cdot 2\end{array}$ \\
\hline 4 & $\begin{array}{l}\text { I } \\
2 \\
3\end{array}$ & $\begin{array}{r}18 \cdot 35 \\
9 \cdot 23 \\
12 \cdot 54\end{array}$ & $\begin{array}{l}37 \cdot 64 \\
29 \cdot 68 \\
29 \cdot 72\end{array}$ & $\begin{array}{l}19 \cdot 29 \\
20 \cdot 45 \\
17 \cdot 18\end{array}$ & $\begin{array}{l}5 I \cdot 2 \\
68 \cdot 9 \\
57 \cdot 8\end{array}$ & $\begin{array}{l}55 \cdot 8 \\
68 \cdot 7 \\
56 \cdot 5\end{array}$ \\
\hline 5 & $\begin{array}{l}\mathrm{I} \\
2 \\
3\end{array}$ & $\begin{array}{l}26 \cdot 19 \\
15 \cdot 83 \\
12 \cdot 23\end{array}$ & $\begin{array}{l}30.53 \\
31.09 \\
30.75\end{array}$ & $\begin{array}{r}4 \cdot 34 \\
15 \cdot 26 \\
18 \cdot 52\end{array}$ & $\begin{array}{l}14 \cdot 2 \\
49 \cdot 1 \\
60 \cdot 2\end{array}$ & $\begin{array}{l}26 \cdot 4 \\
50 \cdot 0 \\
66 \cdot 6\end{array}$ \\
\hline Over & mean & 15.6 & $34 \cdot 0$ & I $8 \cdot 4$ & $54^{\circ} 0$ & $56 \cdot 8$ \\
\hline
\end{tabular}

* Calculated as in equation (5) (p. 30) from the composition of the capsule mixture and $\mathrm{Cr}_{2} \mathrm{O}_{3}$ output.

\section{DISCUSSION}

\section{Use of $\mathrm{Cr}_{2} \mathrm{O}_{3}$ as a marker}

It is worthy of note that the amount of $\mathrm{Cr}_{2} \mathrm{O}_{3}$ used by others in studies of digestion has been $\mathrm{x} \%$ of the dry diet. Carotene being a trace constituent of the food, we thought it best to use only $0.1 \% \mathrm{Cr}_{2} \mathrm{O}_{3}$ in the production ration in all our experiments (Chanda et al. $\left.\mathrm{I} 95^{\mathrm{I}} a, b\right)$. Accordingly we used only I $\mathrm{g}$ of $\mathrm{Cr}_{2} \mathrm{O}_{3}$, which is little enough to be easily introduced into a gelatin capsule of a size suitable for administration to goats and which does not result in too small a ratio of carotene to $\mathrm{Cr}_{2} \mathrm{O}_{3}$ in the faeces. 


\section{The fate of the carotene which failed to reappear in the faeces}

There is room for conjecture as to the fate of the carotene which failed to reappear in the faeces, though part of it must have been absorbed for transformation into vitamin A by the small intestine. In the British Saanen goat, whose milk is white, carotene itself is absorbed only in traces for it cannot be determined in the blood or the milk but is present in both the liver and colostrum in amounts which vary from zero to easily measurable quantities (Chanda \& Owen, I952; Owen \& Proudfoot, unpublished observations).

In our earlier experiments with lactating cows, thyroxine was found to increase the concentration and amount of vitamin $A$ in the milk (Chanda \& Owen, 1952). In experiments which were published separately but which were in fact done on the same cows at the same time it was found that thyroxine increased the disappearance of carotene (Chanda et al. 195 I $b$; Chanda $\&$ Owen, 1952). In these same experiments, thiouracil had equally pronounced, but opposite, effects-it decreased the amount of vitamin $A$ in the milk and at the same time the carotene in the faeces increased. Similar effects have been reported from work with rats (Cama \& Goodwin, 1949; Cama, Pillai, Sundaresan \& Venkateshan, 1957) and from work with chickens (Chanda, 1956). There can be little doubt that in the experiments of Chanda et al. $\left(195^{1} b\right)$ and of Chanda \& Owen $\left(195^{2}\right)$ the carotene of the food was appearing in the milk as vitamin A. Carotene dissolved in olive oil and subcutaneously injected does not give rise to carotene or vitamin $A$ in the blood of goats (Chanda $\&$ Owen, unpublished observations).

\section{SUMMARY}

I. In three experiments an intimate mixture of $\beta$-carotene dissolved in fat with $\mathrm{Cr}_{2} \mathrm{O}_{3}$ was given as a single $2 \mathrm{~g}$ dose in a gelatin capsule to a goat eating a diet devoid of carotene or other known precursor of vitamin A. Every sample of faeces produced after dosing was analysed for carotene and $\mathrm{Cr}_{2} \mathrm{O}_{3}$.

2. Faeces remained free from $\mathrm{Cr}_{2} \mathrm{O}_{3}$ or carotene until about $\mathrm{I}_{2} \mathrm{~h}$ after the capsule had been given. Thereafter both carotene and $\mathrm{Cr}_{2} \mathrm{O}_{3}$ were present for about $2 \frac{1}{2}$ days. After $72 \mathrm{~h}$ the faeces were again carotene-free.

3. There were pronounced simultaneous maxima in the reappearance of $\mathrm{Cr}_{2} \mathrm{O}_{3}$ and carotene in the faeces and a parallelism between the rates at which they reappeared.

4. Estimates of the amount of carotene disappearing, whether calculated by regression of the faecal concentrations of carotene on $\mathrm{Cr}_{2} \mathrm{O}_{3}$ or by comparing outputs of carotene with intakes corrected by using the $\mathrm{Cr}_{2} \mathrm{O}_{3}$ outputs, were the same.

5. After a week on the carotene-free diet after a diet containing dried grass, the faeces of goats became free from carotene and the residual carotene found previously in the faeces of cows on a similar diet was not observed.

6. In a fourth experiment capsules containing $2 \mathrm{~g}$ of the same mixture were given at the rate of one daily to five goats.

7. Outputs of $\mathrm{Cr}_{2} \mathrm{O}_{3}$ indicated that the inability of the animal to mix the ingested $\mathrm{Cr}_{2} \mathrm{O}_{3}$ evenly with its digesta had resulted in a bias in the sampling of the faeces. This 
bias varied from period to period and from goat to goat so that the ratio of output to intake of $\mathrm{Cr}_{2} \mathrm{O}_{3}$ ranged from 0.88 to $\mathrm{I} \cdot 37$.

8. From the outputs of $\mathrm{Cr}_{2} \mathrm{O}_{3}$, intakes of carotene were corrected for this bias in sampling. The difference between the true intakes, so calculated, and the carotene outputs gave the amount of carotene disappearing, which averaged $18.4 \mathrm{mg} /$ goat/day over the whole experiment. The losses of the carotene averaged $54 \%$.

9. The losses of carotene were also calculated from the rectilinear regression of the concentrations of carotene on those of $\mathrm{Cr}_{2} \mathrm{O}_{3}$ in the faeces. The results were of similar magnitude to those obtained by using faecal $\mathrm{Cr}_{2} \mathrm{O}_{3}$ to calculate the carotene intakes.

10. The loss of carotene dissolved in fat was found to be of the same order of magnitude as the loss of carotene in dried grass in previous experiments from this laboratory.

We thank Miss S. McLauchlan, Miss M. Lightbody and Miss E. Taylor for analytical work during Exps. $\mathrm{I}-3$ and Miss H. Chesney for similar help in Exp. 4. Assistance with animal management was provided by Miss S. Hirst during Exps. $1-3$ and by Mr J. Broadley during Exp. 4 .

\section{REFERENCES}

Balch, C. C. (1950). Brit. F. Nutr. 4, 36r.

Balch, C. C. \& Johnson, V. W. (1950). Brit. F. Nutr. 4, 389.

Balch, C. C. \& Kelly, A. (1950). Brit. F. Nutr. 4, 395.

Cama, H. R. \& Goodwin, T. W. (I 949). Biochem. F. 45, 236.

Cama, H. R., Pillai, N. C., Sundaresan, P. R. \& Venkateshan, C. (1957). F. Nutr. 63, 57 I.

Chanda, R. (1956). Nature, Lond., 178, 541.

Chanda, R., Clapham, H. M., McNaught, M. L. \& Owen, E. C. (I95 I a). F. agric. Sci. 4r, 179.

Chanda, R., Clapham, H. M., McNaught, M. L. \& Owen, E. C. (195 I b). Biochem. F. 50, 95.

Chanda, R., Clapham, H. M. \& Owen, E. C. (1954). Biochem. F. 56, 453.

Chanda, R., Clapham, H. M. \& Owen, E. C. (1955 a). Biochem. F. 60, 391 .

Chanda, R., Clapham, H. M. \& Owen, E. C. (1955b). Voeding, 16, 778.

Chanda, R. \& Owen, E. C. (1952). Biochem. F. 51, 404.

Crossland, A., Owen, E. C. \& Proudfoot, R. (1958). Brit. F. Nutr. 12, 312.

Keener, H. A., Bechdel, S. I., Guerrant, N. B. \& Thorp, W. T. S. (1942). F. Dairy Sci. 25, 571.

Moore, J. H. (1957). Brit. F. Nutr. I1, 273.

Moore, J. H. (1958). Brit. F. Nutr. 12, 24.

Owen, E. C. (1954). F. Dairy Res. 21, 408.

Raymond, W. F. \& Minson, D. J. (x955). F. Brit. Grassl. Soc. 1o, 282.

Stewart, J., McCallum, J. W. \& Watts, P. S. (1952). F. comp. Path. 62, 237. 